\title{
Nuclear Factor-Kappa B I Inhibits Early Apoptosis of Glioma Cells by Promoting the Expression of Bcl-2 [Retraction]
}

Yang TQ, Chen M, Wang YQ, et al. Onco Targets Ther. 2017;10:4305-4313.

The Editor and Publisher of OncoTargets and Therapy wish to retract the published paper. Concerns were raised that some of the western blots shown in Figure 4B, 4C and $4 \mathrm{D}$ may have been duplicated. The authors were unable to provide a satisfactory explanation for the alleged duplication and they were unable to provide satisfactory raw data for the western blots shown in the paper. The findings of the study were deemed to be invalid and the decision was made to retract the article.

Our decision-making was informed by our policy on publishing ethics and integrity and the COPE guidelines on retraction.

The retracted article will remain online to maintain the scholarly record, but it will be digitally watermarked on each page as "Retracted".

\section{Publish your work in this journal}

OncoTargets and Therapy is an international, peer-reviewed, open access journal focusing on the pathological basis of all cancers, potential targets for therapy and treatment protocols employed to improve the management of cancer patients. The journal also focuses on the impact of management programs and new therapeutic agents and protocols on patient perspectives such as quality of life, adherence and satisfaction. The manuscript management system is completely online and includes a very quick and fair peer-review system, which is all easy to use. Visit http://www.dovepress.com/ testimonials.php to read real quotes from published authors. 